\title{
Subjective Well-Being pada Pekerja Perempuan
}

\author{
Magister Psikologi Sains Universitas Ahmad Dahlan \\ Haris Munandar \\ Magister Psikologi Sains Universitas Ahmad Dahlan \\ haris10013023@webmail.uad.ac.id \\ Nina Zulida Situmorang \\ Magister Psikologi Sains Universitas Ahmad Dahlan \\ nina.situmorang@psy.uad.ac.id \\ Fatwa Tentama \\ Magister Psikologi Sains Universitas Ahmad Dahlan \\ fatwa.tentama@psy.uad.ac.id
}

\begin{abstract}
Abstrak
Kajian ini bertujuan untuk mengetahui subjective well-being atau kesejahteran subjektif pada pekerja perempuan. Kajian ini menggunakan pendekatan kajian pustaka untuk mendalami informasi mengenai subjective wellbeing atau kesejahteraan subjektif pada pekerja perempuan. Kajian pustaka ini akan memberikan gambaran subjective well-being pada pekerja perempuan yang meliputi keadaan subjek pada saat bekerja, beradaptasi dengan lingkungan kerja, perasaan atau afektif saat bekerja, dan hikmah menuju kesejahteraan subjektif. Kajian lainnya meliputi faktor-faktor yang mempengaruhi subjective well-being pada pekerja perempuan yaitu peran suami, peran keluarga, dan kondisi lapangan pekerjaan yang menjadikan pekerja dilematis.
\end{abstract}

Kata kunci: subjective well-being, pekerja, perempuan

\section{Pendahuluan}

Pembahasan manusia sebagai ciptaan Tuhan yang maha esa tidak akan pernah ada habisnya. Manusia bekerja karena berbagai tujuan. Tujuan utama seseorang bekerja adalah mencari nafkah agar mendapatkan hal-hal mendasar yang dibutuhkan seperti makanan, pakaian, dan tempat tinggal. Tujuan bekerja yang lebih tinggi tingkatannya adalah untuk berkarir atau mengembangkan diri. Jenis pekerjaan yang dilakukan oleh manusia dapat mempengaruhi bagaimana manusia dapat memenuhi kebutuhan hidupnya itu. Seorang yang bekerja dan senang terhadap pekerjaannya akan memperlihatkan berbagai macam perilaku yang mencerminan kesenangannya (Munandar, 2008). Senang terhadap pekerjaan yang dilakukan dapat diartikan sebagai kenyamanan terhadap pekerjaan. 
Pada masa sekarang ini tidak hanya laki-laki atau suami yang bekerja untuk memenuhi kebutuhan keluarga, perempuan tau seorang istri ikut berperan dalam meningkatkan kesejahteraan keluarga dengan cara bekerja. Eksistensi perempuan saat ini tidak hanya meningkatkan penghasilan karena tuntutan ekonomi keluarga. Perempuan memiliki beberapa potensi yang juga tidak kalah dibanding dengan laki-laki, baik dari segi intelektual, kemampuan, maupun keterampilan (Ridzal, 2000).

Semakin banyaknya perempuan bekerja akan menjadi fenomena penting untuk diperhatikan, salah satunya terkait kesejahteraan subjektif pada perempuan yang bekerja, hal ini dikarekanan tinggi rendahnya kesejahteraan subjektif pada perempuan akan berdampak pada suatu organisasi ataupun industri. Menurut Kuykendall dan Tay (2015), pentingnya memperhatikan subjective well-being karyawan atau pekerja untuk organisasi dikarekanan akan berdampak terhadap stres dan sumber daya, dengan memfokuskan pada subjective well-being karyawan atau pekerja akan bisa mengurangi stres dan meningkatkan sumber daya di organisasi.

Istilah subjective well-being merupakan evaluasi seseorang mengenai hidupnya pada masa sekarang, pada momen tertentu maupun bertahun tahun yang lalu. Bentuk dari evaluasi tersebut meliputi reaksi emosional seseorang pada suatu kejadian, suasana hati, dan penilaian dari kepuasan hidup, pemenuhan kebutuhan dan kepuasan domain seperti pernikahan dan pekerjaan (Diener dan Scollon, 2003). Istilah lainnya juga subjective well-being diperlukan sebuah kekuatan dan kebajikan yang dipahami oleh masing-masing personal. Kekuatan dan kebajukan adalah karakteristik positif yang menimbulkan perasaan senang dan gratifitas (Seligman, 2005).

Berdasarkan uraian diatas maka tujuan kajian pustaka ini akan membahas mengenai subjective well being pada pekerja perempuan.

\section{Tinjauan Pustaka}

Diener dan McGavran (2008) mendefinisikan subjective well being sebagai konsep psikologis dalam kehidupan individu yang mengandung beberapa 
dimensi antara lain: kepuasan hidup, kepuasan terhadap hal-hal penting dalam kehidupan, perasaan positif yang tinggi, dan perasaan negatif yang rendah. Definisi yang mirip juga disampaikan oleh Headey dan Wooden (2004) yaitu subjective well being mengandung dimensi kepuasan hidup dan perasaan yang positif seperti vitalitas dan perasaan nyaman. Headey dan Wooden (2004) juga menambahkan bahwa subjective well-being lebih ditentukan oleh sifat kepribadian, seperti hubungan personal, dan partisipasi individu dalam kehidupan sosial.

Heshmati, Bajalan, dan Tausch, (2007) menyatakan bahwa Subjective well being merefleksikan bagaimana merasakan diri dan lingkungannya. Heshmati Bajalan dan Tausch, (2007) mengembangkan studinya fokus pada bagaimana seorang individu merasakan derajat kesehatan, kesejahteraan personal dan kesejahteraan dalam akses pendidikan sebagai bagian dari tumbuh kembang. Boglarsky dan Kwantes (2005) memelengkapi bahwa subjective well being mempengaruhi beberapa dimensi penting dalam kehidupan manusia, seperti kemampuan menjalin hubungan sosial, kreativitas, peningkatan kesehatan, dan kepuasan dalam sebuah pernikahan.

Diener dan Scollon (2003) menyebut ada dua aspek utama kesejahteraan subyektif, yaitu kepuasan hidup dan afek (perasaan positif dan perasaan negatif). Uraian di bawah ini akan membahas masing-masing aspek ditinjau dari pandangan ahli psikologi.

Menurut Diener dan Lucas (1999) afek adalah gabungan dari mood dan emosi, maksudnya ketika berbicara tentang afek maka sering muncul istilah mood. Dalam istilah mood tercakup pengertian yang lebih khusus, yakni suatu kondisi perasaan yang berulang-ulang tetapi dengan intensitas yang bisa dikatakan masih ringan. Afek dapat dipengaruhi oleh nilai-nilai yang ada atau yang dianut. Afek orang beragama akan dipengaruhi oleh nilai-nilai agamanya. Pada kajian ini afek diartikan sebagai suasana hati yang dialami individu dalam menikmati pengalaman-pengalamannya di masa lalu dan sekarang. Jika individu memiliki afek positif maka dia akan bersemangat, aktif, yang ditandai dengan energi yang tinggi, penuh konsentrasi, dan penuh kenyamanan. Sedangkan jika memiliki afek 
negatif, individu tersebut akan merasakan ketegangan dan ketidak nyamanan sebagai akibat dari berbagai mood yang tidak mengenakkan seperti marah dan lain sebagainya.

Sedangkan kepuasan hidup menurut Diener, Oishi, dan Lucas (2009) adalah kemampuan seseorang untuk menikmati pengalaman-pengalamannya disertai dengan kegembiraan. Kepuasan merupakan hasil dari perbandingan antara segala peristiwa yang dialami dengan harapan dan keinginan. Tingkat keberhasilan individu ketika memecahkan masalah penting dalam kehidupannya juga mempengaruhi kepuasan hidup individu tersebut.

Berdasarkan uraian diatas maka aspek-aspek subjective well being meliputi kepuasan hidup dan afek (perasaan positif dan perasaan negatif).

Terdapat enam hal yang dapat dijadikan sebagai prediktor terbaik dalam mengetahui kebahagiaan dan kepuasan dalam hidup atau yang biasa disebut dengan faktor-faktor yang mempengaruhi subjective well being (Diener \& Lucas, 1999). Pertama, harga diri positif akan menyebabkan seseorang memiliki kendali yang baik terhadap rasa marah, mempunyai hubungan yang intim dan baik dengan orang lain, dan kapasitas produktif dalam pekerjaan. Hal ini akan membantu individu untuk mengembangkan kemampuan dalam hubungan interpersonal yang baik serta menciptakan kepribadian yang sehat. Kedua, Kontrol diri yang diartikan sebagai keyakinan individu bahwa ia akan mampu berperilaku dengan cara yang tepat ketika menghadapi suatu peristiwa. Kontrol diri melibatkan proses pengambilan keputusan, mampu mengerti, memahami serta mengatasi konsekuensi dari keputusan yang telah diambil serta mencari pemaknaan atas peristiwa tersebut. Ketiga, ekstraversi yang diartikan sebagai Individu dengan kepribadian ekstrovert akan tertarik pada hal-hal yang terjadi di luar dirinya, seperti lingkungan fisik dan sosialnya. Keempat, optimisme yang diartikan sebagai individu yang optimis mengenai masa depan merasa lebih bahagia dan puas dengan kehidupannya. Individu yang mengevaluasi dirinya dengan cara yang positif, akan memiliki kontrol yang baik terhadap hidupnya sehingga individu memiliki impian dan harapan yang positif tentang masa depan. Kelima, Relasi sosial yang positif akan tercipta bila adanya dukungan sosial dan keintiman 
emosional. Hubungan yang didalamnya terdapat dukungan dan keintiman akan membuat individu mampu mengembangkan harga diri, meminimalkan masalahmasalah psikologis, kemampuan pemecahan masalah yang adaptif, dan membuat individu menjadi sehat secara fisik. Keenam, memiliki arti dan tujuan dalam hidup yang sering dikaitkan dengan konsep religiusitas. Penelitian menyebutkan bahwa terdapat korelasi positif antara konsep religiusitas dengan kesejahteraan psikologis dimana individu yang memiliki kepercayaan religi yang besar akan memiliki kesejahteraan psikologis yang besar pula.

Berdasarkan uraian diatas maka faktor-faktor yang mempengaruhi subjective well-being adalah harga diri positif, kontrol diri, ekstraversi, optimisme, relasi sosial yang positif, memiliki arti dan tujuan hidup.

\section{Metode}

Pada kajian ini penulis menggunakan metode kajian pustaka untuk mengetahui subjective well-being atau kesejahteraan subjektif pada pekerja perempuan dengan literarture review pada penelitian-penelitian terdahulu.

\section{Pembahasan}

Hasil penelitian lain oleh Trzcinski dan Holst (2010) mengenai perbedaan gender dalam subjective well-being diperoleh hasil bahwa, perempuan yang bekerja memperoleh subjective well-being yang lebih tinggi dibandingkan dengan perempuan yang tanpa pekerjaan di luar rumah. Upaya menciptakan masyarakat yang luas dan transformasi norma sosial dasar mengenai harapan untuk perempuan memilih orientasi menuju kesuksesan profesional dan orientasi terhadap keluarga perempuan membutuhkan kebijakan, praktek dan norma-norma sosial untk berubah sehingga mereka memilih kesempatan yang sama dengan lakilaki memenuhi beberapa nilai dan orientasi.

Perempuan yang bekerja akan cenderung memiliki kondisi emosi yang lebih stabil dibandingkan dengan perempuan yang tidak bekerja. hal ini sejalan dengan hasil penelitian yang dilakukan oleh Bericat (2016) mengenai subjective well-being pada pekerja perempuan ditemukan bahwa, perempuan cenderung 
subjective well-being tinggi jika mendapatkan pekerjaan tetap atau memperoleh pekerjaan kontrak, hal ini disebabkan perempuan yang bekerja cenderung mempunyai sosial emosional yang bagus dibandingkan perempuan yang tidak bekerja atau pengangguran.

Orientasi menuju kesuksesan yang profesional dan orientasi terhadap keluarga menjadikan wanita harus ekstra membagi waktu atas ketersediaannya dalam bekerja, akan tetapi perempuan yang bekerja sebagai wanita karir cenderung tingkat kepuasan hidupnya menjadi tinggi dibandingkan dengan perempuan yang hanya berstatus pekerja dalam rumah tangga. Perempuan yang bekerja dikarenakan laar belakang pendidikan akan mempengaruhi tingginya kesejahteraan subjektif. Trzcinski dan Holst (2010) menjelaskan hasil penelitiannya bahwa perbedaan yang diamati pada perempuan yang dalam posisi bekerja di dalam rumah tangga tanpa pekerjaan diluar rumah dilaporkan tingkat kepuasan hidup yang lebih rendah dibandingkan dengan perempuan yang bekerja diluar rumah.

Faktor yang mempengaruhi kesejahteraan subjektif pada pekerja perempuan adalah adanya kestabilan dalam menjaga pekerjaan rumah sekaligus karirnya dalam pekerjaan, jika tidak akan mempengaruhi menururnya kesejahteraan subjektif pekerja perempuan. Yang dan Miller (2008) mengatakan bahwa terdapat beberapa faktor yang dapat menimbulkan menurunnya kesejahteraan subjektif pada wanita karir antara lain karena adanya konflik kerja, memburuknya kesehatan mental, disfungsi keluarga, kelelahan, dan menurunnya kesejahteraan dalam hubungan suami istri. Selain itu juga, peran suami dalam memberikan dukungan sosial pada istri yang bekerja juga sangat bermakna. Hal ini di pertegas oleh penelitian Apollo dan Andi (2012) yang mengungkapkan ketidakbahagiaan wanita karir disebabkan oleh adanya rasa tertekan, kurangnya dukungan suami, konflik kehadiran anak, tingginya tuntutan dan masalah dalam pekerjaan, hubungan antar anggota keluarga yang kurang harmonis, tingginya kebutuhan finansial dan tidak tercapainya aktualisasi diri.

Penting juga untuk dipelajari, faktor yang mempnegaruhi kesejahteraan subjektif perempuan yang bekerja adalah status perkawinan perempuan yang 
sudah memiliki anak yang banyak cenderung akan mengalami stres karena menjadi dua peran sekaligus bekerja di dalam dan di luar rumah, sedangkan status perkawinan yang masih muda atau hanya memiliki satu anak cenderung tinggi kesejahteraan subjektifnya. Maurya dan Agarwal (2015) menjelaskan bahwa kesejahteraan perempuan yang bekerja dipengaruhi oleh konflik peran dalam keluarga yang rendah, hubungan suami-istri yang harmonis, dan dukungan penuh suami yang tinggi. Sebaliknya, jika hubungan keharmonisan keluarga cenderung rendah akan berdampak stres terhadap perempuan yang bekerja. Daukantaite (2006) menjelaskan bahwa faktor penting yang harus diperhatikan kesejahteraan perempuan yang bekerja adalah status perkawinan dan tingkat pengangguran yang rendah sehingga perempuan bekerja hanya sebagai tambahan ekonomi keluarga untuk persiapan masa depan.

Hasil penelitian Wulandari dan Widyastuti (2014) mengenai faktor-faktor kebahagiaan di tempat kerja diperoleh bahwa ada lima faktor yang membuat sesorang bahagia di tempat kerja yaitu, hubungan positif dengan orang lain seperti dukungan dari rekan kerja dan atasan, prestasi seperti keberhasilan menyelesaikan tugas, kesesuaian pekerjaan, dan mengembangkan diri, lingkungan kerja fisik seperti fasilitas, kompensasi seperti gaji dan insentif, dan kesehatan seperti badan sehat dan rileks. Secara garis besar, dari beberapa faktor tersebut faktor hubungan positif dengan orang lain memiliki presentase terbesar. Hal ini menunjukkan bahwa hubungan positif sesama rekan kerja merupakan salah satu sumber kebahagiaan di tempat kerja.

\section{KESIMPULAN}

Berdasarkan pembahasan diatas maka dapat disimpulkan bahwa subjective well-being atau kesejahteraan subjektif pada pekerja perempuan meliputi perasaan positif yang dialami pada saat bekerja yang dan orientasi motivasi perempuan dalam mencapai sisi profesionalnya sebagai pekerja diluar rumah yang yang menjadikan perempuan merasa puas terhadap kehidupannya. Sedangkan faktorfaktor yang mempengaruhi kesejahteraan subjektif perempuan yang bekerja 
adalah status perkawinan, hubungan keluarga, dukungan suami, dan hubungan dengan rekan kerja di tempat kerja.

\section{DAFTAR PUSTAKA}

Apollo., \& Andi, C. (2012). Konflik peran ganda perempuan menikah yang bekerja ditinjau dari dukungan sosial keluarga dan penyesuaian diri. Tesis. Universitas Katolik Widya Mandala Madiun.

Bericat, E. (2016). The subjective well-being of working women in europe. Handbook on Well-Being of Working Women. International Handbooks of Quality-of-Life.

Boglarsky, C.A \& Kwantes, C.T (2005). Who is happy and why?. Subjective wellbeing and associative thinking styles of US and Canadian students. Presented of 17th Annual convention of the American psychological society, Boston.

Daukantaite, D. (2006). Subjective well-being in Swedish women, Disertation. Department of Psychology: Stockholm University.

Diener, E. \& Lucas, R.E. (1999). Personality and subjective well-being. Journal Well-being the foundations of hedonic psychology, 213-229. America: Russell Sage Foundation.

Diener, E., \& Scollon, C. (2003). Subjective well-being is desirable, but not the summum bonum. Paper delivered at the University of Minnesota interdisciplinary Workshop on Well-Being, October 23-25, 203, Minneapolis.

Diener, M. L., \& McGavran, M. B. (2008). What Makes People Happy? A Developmental Approach to The Literature on Family Relationships and Well-being. In M. Eid, \& R. J. Larsen The Science of Subjective Wellbeing. New York: Guilford Press.

Diener, E., Oishi, S., \& lucas, R. E. (2009). Subjective well-being: the science of happiness and life satisfaction. In S J Lopez \& C.R. Snyder (Eds.), Oxford handbook of positive psychology. New York: Oxford University Press.

Headey, B., \& Wooden, M. (2004). The Effects of Wealth and Income on Subjective Well-Being and III-Being. Economic Record, 80(1), 24-33.

Heshmati, A., Bajalan, C. S. J., \& Tausch, A. (2007). Measurement and analysis of child well being in middle and high income countries. IZA Discussion Paper. No. 3203.

Kuykendall, L., \& Tay, L. (2015). Employee subjective well-being and physiological functioning: An integrative model. Health Psychology Open. $1-11$. 
Maurya, K. K. \& Agarwal, M. (2015). Factors affecting stress and wellbeing of women employees. Psychology of Women: Research issues and trends. 63-75.

Munandar, A. S. (2008). Psikologi industri dan organisasi. Jakarta: Universitas Indonesia (UI Press).

Ridzal. F. (2000). Dinamika gerakan perempuan di indonesia. Yogyakarta: Tiara Wacana

Seligman, M. (2005). Authentic happiness: Menciptakan kebahagiaan dengan psikologi positif. Penerjemah: Eva Yulia Nukman. Bandung: PT Mizan Pustaka.

Trzcinski, E., \& Holst, E. (2010). Gender differences in subjective well-being in and out of management positions. IZA Discussion Paper. 5116.

Wulandari, S., \& Widyastuti, A. (2014). Faktor-faktor kebahagiaan di tempat kerja. Jurnal Psikologi, 10(1), 49-59.

Yang, K., \& Miller, G. J. (2008). Hanbook of research methods in public administration. United States of America: Aurebach Publications 